\title{
Burden of anemia and its associated factors among pregnant women of Vindhya region: prospective observational study
}

\author{
Suman Yadav, Kalpana Yadav*, Padma Shukla \\ Department of Obstetrics and Gynecology, Shyam Shah Medical College, Rewa, Madhya Pradesh, India
}

Received: 20 June 2020

Accepted: 10 August 2020

*Correspondence:

Dr. Kalpana Yadav,

E-mail: jiya271190@gmail.com

Copyright: $\odot$ the author(s), publisher and licensee Medip Academy. This is an open-access article distributed under the terms of the Creative Commons Attribution Non-Commercial License, which permits unrestricted non-commercial use, distribution, and reproduction in any medium, provided the original work is properly cited.

\begin{abstract}
Background: Anemia is major public health problem. It is especially prevalent in women of reproductive age, particularly during pregnancy. It affects both developed and developing countries. According to the National Family Health Survey, anemia is prevalent in approximately $53.1 \%$ of non-pregnant and $50.1 \%$ of pregnant women. Objective of this study was to study the prevalence of anemia in pregnant women of Vindhya region and also various degree of anemia and factors associated.

Methods: All pregnant women attending the outdoor and indoor of the obstetrics and gynecology department of, GMH. Rewa, taken for calculation of prevalence of anaemia and among them 510 pregnant women were selected who were satisfying inclusion and exclusion criteria for studying association factors. Study period was 1 year. Haemoglobin estimation done by sahlis haemoglobinometer.

Results: Prevalence of anaemia figures $81 \%$, Out of them, $38.05 \%$ mild, $33.26 \%$ moderate and $7.80 \%$ of women were severely anemic. Maximum number of women were housewives $71.1 \%$. Anaemia was found more commonly among those who are either taking iron prophylaxis irregularly or not taking. High prevalence was noted among those pregnant women who had $<4$ antenatal visits i.e., $54.51 \%$.

Conclusions: Considering the high prevalence of anaemia in Vindhya region, extensive efforts should be made not only to correct anaemia, but to prevent anaemia. Various programmes for anaemia control should be executed more resourcefully to overcome it. Strong reinforcement of government scheme should be done at Anganwadi, $\mathrm{CH}, \mathrm{PHC}$ to ensure prevention as well as early detection of anaemia.
\end{abstract}

Keywords: Anaemia, Antenatal care, Pregnancy

\section{INTRODUCTION}

Anemia is one of the most frequently observed nutritional diseases in the world and major public health problem. It is especially prevalent in women of reproductive age, particularly during pregnancy. WHO defines anemia as less than $11 \mathrm{gm} / \mathrm{dl}$ in the first and third trimester and less than $10.5 \mathrm{gm} / \mathrm{dl}$ in second trimester. ${ }^{1}$ The main causes of anemia in developing countries include: inadequate intake and poor absorption of iron, early age at marriage, teenage pregnancy, ill spacing between two pregnancies, blood loss during labour and delivery, heavy menstrual blood flow, malaria, hookworm infestation, genetic disorders (e.g., sickle cell and thalassemia). ${ }^{2-4}$ According to the NFHS 4, anemia is prevalent in approximately $53.1 \%$ of non-pregnant and $50.1 \%$ of pregnant women in India, and in Rewa, Madhya Pradesh it is $40.8 \%$ in nonpregnant and $44 \%$ in pregnant women. ${ }^{5,6}$

\section{Aims and objectives}

The objectives of the study were to study the prevalence of anemia in pregnant women of Vindhya region; to find out degree of anemia and to study various factors associated with anemia. 


\section{METHODS}

Prevalence of anaemia was calculated in 20608 antenatal cases attending the outdoor and indoor of the department of obstetrics and gynecology of GM Hospital Rewa. Sample size for the study was calculated by using single population proportion formula with a $95 \%$ confidence interval, $5 \%$ margin of error, and $44 \%$ prevalence of anaemia among pregnant women of Rewa region (according to NFHS-4).

Sample size $(\mathrm{n})=4 \mathrm{pq} / \mathrm{d}^{2}$ Where,

p: prevalence $(44 \%)$,

q-p-q: $(56 \%)$

$\mathrm{d}: 10 \%$ of prevalence $(4.4)$

$\mathrm{n}=4 \times 44 \times 56 / 4.4 \times 4.4=510$

A total of 510 pregnant women were selected was are satisfying inclusion and exclusion criteria for the study.

\section{Inclusion criteria}

All pregnant women attending antenatal OPD and admitted in labour room who had completed 37 weeks of gestation.

\section{Exclusion criteria}

Patient's refusal, patient's already on treatment for anemia, women with complaints of acute blood loss, hemorrhagic disorders, chronic renal disease were closed.

Study period was 1 year, from March 2018 to February 2019. All the women attending OPD and IPD were taken to calculate prevalence and are subjected for haemoglobin estimation by sahlis haemoglobinometer.

With the decided sample size, after obtaining consent detailed history taken and association factors were studied in them. All the subjects were analyzed in full details regarding age, literacy, socio economic status, parity, interval between conceptions, significant past history and other complications associated with anemia were noted.

\section{Hemoglobin percentage}

Quantitative estimation of hemoglobin was done by Sahlis haemoglobinometer.

All the subjects were classified according to WHO criteria i.e. Mild anemia: 10 to $11 \mathrm{gm} / \mathrm{dl}$; moderate anemia: 7 to $9.9 \mathrm{gm} / \mathrm{dl}$; severe anemia: $<7 \mathrm{gm} / \mathrm{dl}$.

\section{Statistical analysis}

Data were entered into a computer using the statistical package for science services (SPSS version 23). Statistical methods employed were the mean, standard deviation (SD), chi-square test.

\section{RESULTS}

Prevalence of anaemia figures $81 \%$ rest were normal i.e., $19 \%$ out of total population. Among them $38.42 \%$ mild, $33.89 \%$ moderate and $7.82 \%$ of women were severely anemic (Table 1).

Out of 510 patients majority of them belonged to the age group of $20-29$ years $(81.56 \%)$ (Table 2$)$.

A total $48.6 \%$ of women were studied up to primary followed by illiterate $(21.1 \%)$ (Table 3$)$.

Anemia was more common among housewives, it is $71.18 \%$ (Table 4).

Most of the anemic women belonged to the lower middle class $(37.25 \%)$ and upper lower class of socioeconomic group $24.71 \%$, respectively (Table 5 ).

Table 1: Prevalence.

\begin{tabular}{|lll|}
\hline Degree of anaemia & Number & Prevalence \\
\hline Mild & 7842 & 38.42 \\
\hline Moderate & 6856 & 33.89 \\
\hline Severe & 1608 & 7.82 \\
\hline Normal & 4302 & 19.87 \\
\hline Total & 20608 & 100 \\
\hline
\end{tabular}

Table 2: Relationship of age with various degree of anaemia in study subjects.

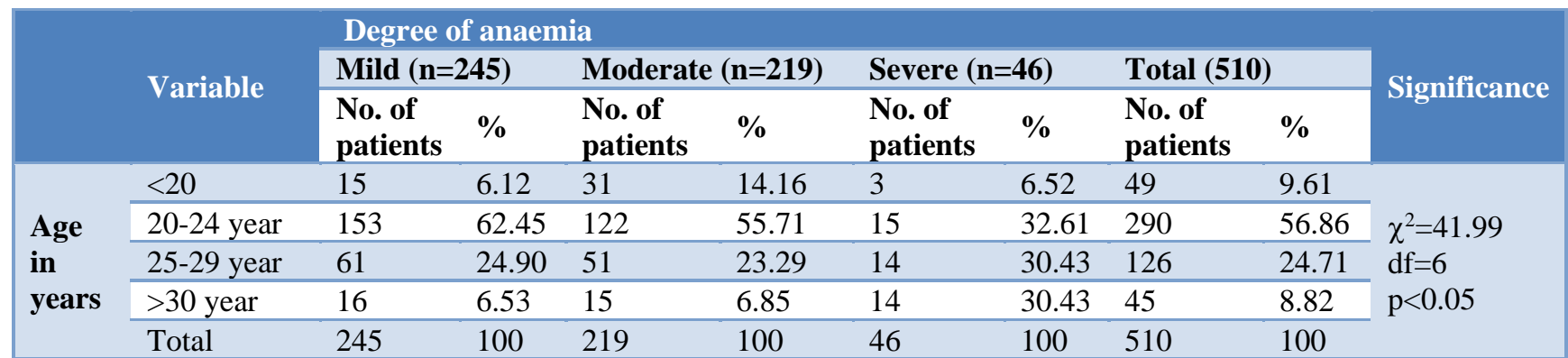


Table 3: Relationship of education with various degree of anaemia in the study subjects.

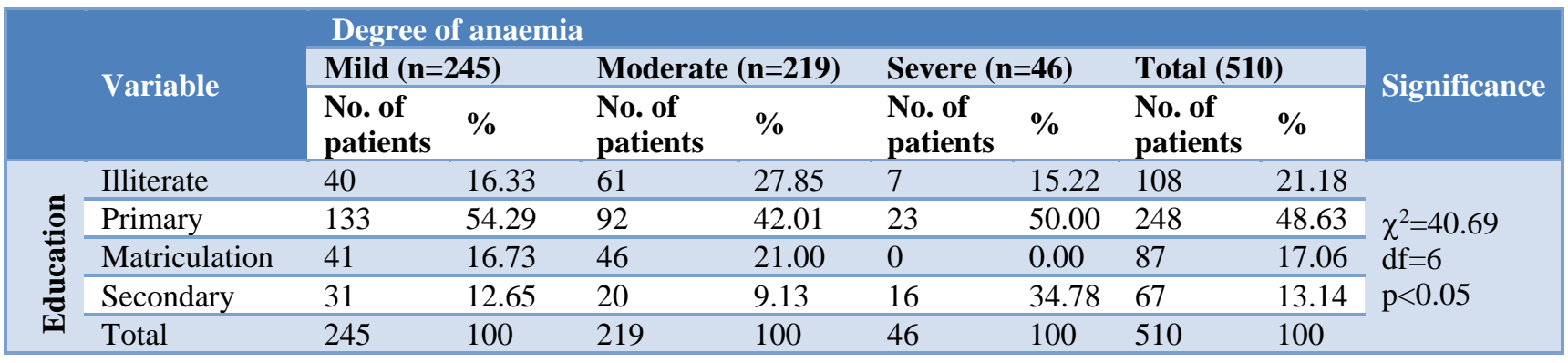

Table 4: Relationship of occupation with various degree of anaemia in the study subjects.

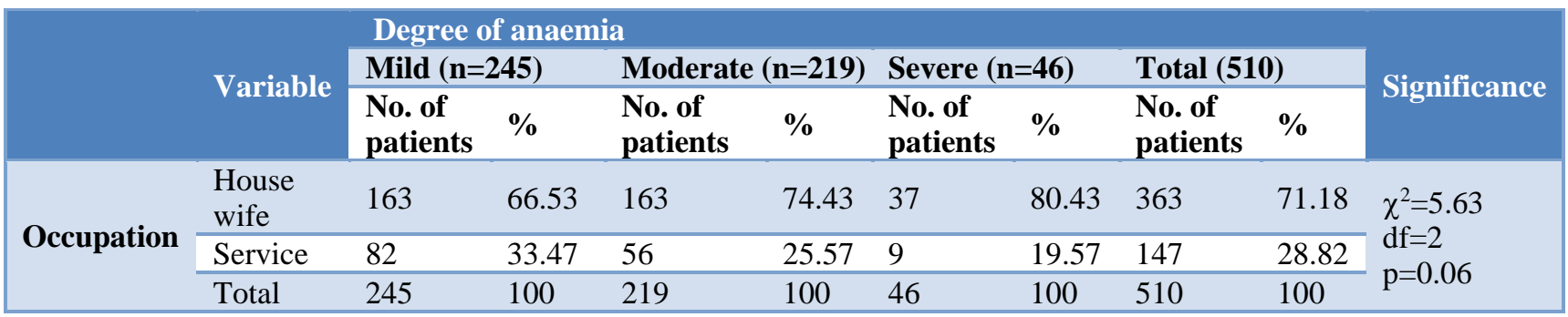

Table 5: Relationship of socio-economic status with various degree of anaemia in the study subjects.

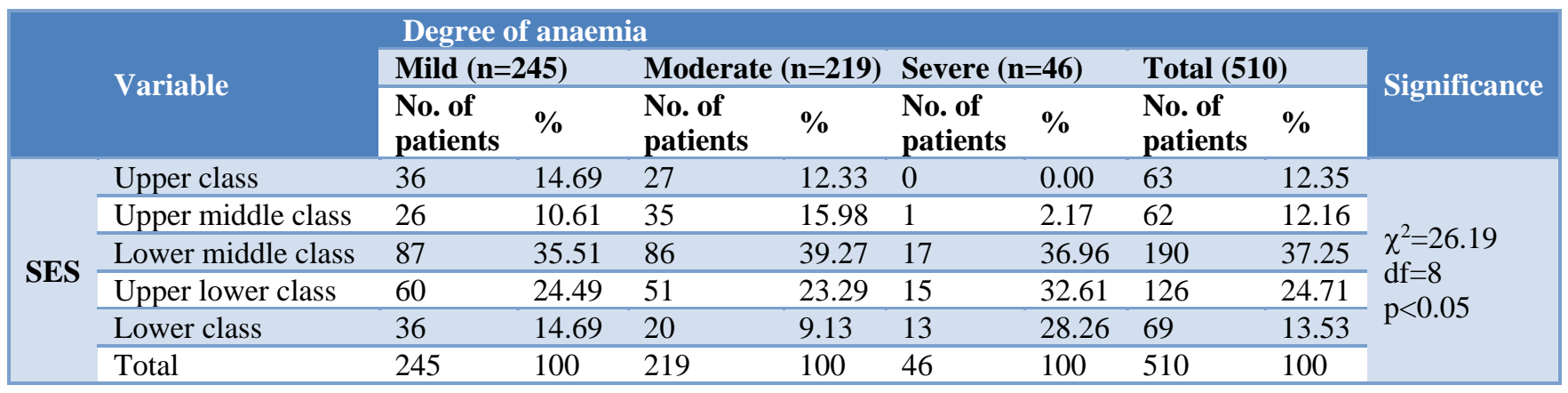

Table 6: Relationship of type of family with various degree of anaemia in the study subjects.

\begin{tabular}{|c|c|c|c|c|c|c|c|c|c|c|}
\hline & & Degree & f anaer & & & & & & & \\
\hline & Variable & Mild (n= & 45) & Modera & $n=219)$ & Severe (I & $=46)$ & Total $(5$ & & \\
\hline & variable & $\begin{array}{l}\text { No. of } \\
\text { patients }\end{array}$ & $\%$ & $\begin{array}{l}\text { No. of } \\
\text { patients }\end{array}$ & $\%$ & $\begin{array}{l}\text { No. of } \\
\text { patients }\end{array}$ & $\%$ & $\begin{array}{l}\text { No. of } \\
\text { patients }\end{array}$ & $\%$ & signincance \\
\hline & Joint & 132 & 53.88 & 122 & 55.71 & 22 & 47.83 & 276 & 54.12 & \\
\hline Type & Nuclear & 52 & 21.22 & 62 & 28.31 & 9 & 19.57 & 123 & 24.12 & $\chi^{2}=10.24$ \\
\hline or & Three generation & 61 & 24.90 & 35 & 15.98 & 15 & 32.61 & 111 & 21.76 & $\mathrm{df}=4$ \\
\hline & Total & 245 & 100 & 219 & 100 & 46 & 100 & 510 & 100 & \\
\hline
\end{tabular}

Table 7: Relationship of religion with various degree of anaemia in the study subjects.

\begin{tabular}{|c|c|c|c|c|c|c|c|c|c|c|}
\hline & \multirow{3}{*}{ Variable } & \multicolumn{8}{|c|}{ Degree of anaemia } & \multirow{3}{*}{ Significance } \\
\hline & & \multicolumn{2}{|c|}{ Mild (n=245) } & \multicolumn{2}{|c|}{ Moderate (n=219) } & \multicolumn{2}{|c|}{ Severe $(n=46)$} & \multicolumn{2}{|c|}{ Total (510) } & \\
\hline & & $\begin{array}{l}\text { No. of } \\
\text { patients }\end{array}$ & $\%$ & $\begin{array}{l}\text { No. of } \\
\text { patients }\end{array}$ & $\%$ & $\begin{array}{l}\text { No. of } \\
\text { patients }\end{array}$ & $\%$ & $\begin{array}{l}\text { No. of } \\
\text { patients }\end{array}$ & $\%$ & \\
\hline \multirow{4}{*}{ Religion } & Hindu & 230 & 93.88 & 183 & 83.56 & 42 & 91.30 & 455 & 89.22 & \multirow{4}{*}{$\begin{array}{l}\chi^{2}=17.27 \\
d f=4 \\
p<0.05\end{array}$} \\
\hline & Muslim & 15 & 6.12 & 26 & 11.87 & 3 & 6.52 & 44 & 8.63 & \\
\hline & Christian & 0 & 0.00 & 10 & 4.57 & 1 & 2.17 & 11 & 2.16 & \\
\hline & Total & 245 & 100 & 219 & 100 & 46 & 100 & 510 & 100 & \\
\hline
\end{tabular}


Table 8: Relationship of pre pregnancy BMI with various degree of anaemia in the study subjects.

\begin{tabular}{|c|c|c|c|c|c|c|c|c|c|c|}
\hline & \multirow{3}{*}{ Variable } & \multicolumn{8}{|c|}{ Degree of anaemia } & \multirow{3}{*}{ Significance } \\
\hline & & \multicolumn{2}{|c|}{ Mild $(n=245)$} & \multicolumn{2}{|c|}{ Moderate $(n=219)$} & \multicolumn{2}{|c|}{ Severe $(n=46)$} & \multicolumn{2}{|c|}{ Total (510) } & \\
\hline & & $\begin{array}{l}\text { No. of } \\
\text { patients }\end{array}$ & $\%$ & $\begin{array}{l}\text { No. of } \\
\text { patients }\end{array}$ & $\%$ & $\begin{array}{l}\text { No. of } \\
\text { patients }\end{array}$ & $\%$ & $\begin{array}{l}\text { No. of } \\
\text { patients }\end{array}$ & $\%$ & \\
\hline \multirow{4}{*}{$\begin{array}{l}\text { Pre } \\
\text { pregnancy } \\
\text { BMI }\end{array}$} & $<18.5$ & 117 & 47.76 & 86 & 39.26 & 31 & 67.39 & 234 & 45.88 & \multirow{4}{*}{$\begin{array}{l}\chi^{2}=35.12 \\
d f=4 \\
p<0.05\end{array}$} \\
\hline & $18.5-24.9$ & 77 & 31.43 & 87 & 39.72 & 12 & 26.09 & 176 & 34.5 & \\
\hline & $>24.9$ & 51 & 20.82 & 46 & 21.00 & 3 & 6.52 & 100 & 19.61 & \\
\hline & Total & 245 & 100 & 219 & 100 & 46 & 100 & 510 & 100 & \\
\hline
\end{tabular}

Table 9: Relationship of weight gain during pregnancy with various degree of anaemia in the study subjects.

\begin{tabular}{|c|c|c|c|c|c|c|c|c|c|c|}
\hline & \multirow{3}{*}{ Variable } & \multicolumn{8}{|c|}{ Degree of anaemia } & \multirow{3}{*}{ Significance } \\
\hline & & \multicolumn{2}{|c|}{ Mild (n=245) } & \multicolumn{2}{|c|}{ Moderate $(n=219)$} & \multicolumn{2}{|c|}{ Severe $(n=46)$} & \multicolumn{2}{|c|}{ Total (510) } & \\
\hline & & $\begin{array}{l}\text { No. of } \\
\text { patients }\end{array}$ & $\%$ & $\begin{array}{l}\text { No. of } \\
\text { patients }\end{array}$ & $\%$ & $\begin{array}{l}\text { No. of } \\
\text { patients }\end{array}$ & $\%$ & $\begin{array}{l}\text { No. of } \\
\text { patients }\end{array}$ & $\%$ & \\
\hline \multirow{5}{*}{$\begin{array}{l}\text { Weight } \\
\text { gain } \\
\text { during } \\
\text { pregnancy } \\
\text { in kg }\end{array}$} & 3 to $5 \mathrm{~kg}$ & 41 & 16.73 & 82 & 37.44 & 14 & 30.43 & 137 & 26.86 & \multirow{5}{*}{$\begin{array}{l}\chi^{2}=35.89 \\
d f=6 \\
p<0.05\end{array}$} \\
\hline & 5.1 to $9 \mathrm{~kg}$ & 76 & 31.02 & 61 & 27.85 & 27 & 58.70 & 164 & 32.16 & \\
\hline & 9.1 to $13 \mathrm{~kg}$ & 77 & 31.43 & 46 & 21.00 & 1 & 2.17 & 124 & 24.31 & \\
\hline & $>13 \mathrm{~kg}$ & 51 & 20.82 & 30 & 13.70 & 4 & 8.70 & 85 & 16.67 & \\
\hline & Total & 245 & 100 & 219 & 100 & 46 & 100 & 510 & 100 & \\
\hline
\end{tabular}

Table 10: Relationship of parity with various degree of anaemia in the study subjects.

\begin{tabular}{|c|c|c|c|c|c|c|c|c|c|c|}
\hline & \multirow{3}{*}{ Variable } & \multicolumn{8}{|c|}{ Degree of anaemia } & \multirow{3}{*}{ Significance } \\
\hline & & \multicolumn{2}{|c|}{ Mild (n=245) } & \multicolumn{2}{|c|}{ Moderate $(n=219)$} & \multicolumn{2}{|c|}{ Severe $(n=46)$} & \multicolumn{2}{|c|}{ Total (510) } & \\
\hline & & $\begin{array}{l}\text { No. of } \\
\text { patients }\end{array}$ & $\%$ & $\begin{array}{l}\text { No. of } \\
\text { patients }\end{array}$ & $\%$ & $\begin{array}{l}\text { No. of } \\
\text { patients }\end{array}$ & $\%$ & $\begin{array}{l}\text { No. of } \\
\text { patients }\end{array}$ & $\%$ & \\
\hline \multirow{5}{*}{ Parity } & 1 & 51 & 20.82 & 36 & 16.44 & 8 & 17.39 & 95 & 18.63 & \multirow{5}{*}{$\begin{array}{l}\chi^{2}=27.49 \\
d f=6 \\
p<0.05\end{array}$} \\
\hline & 2 & 122 & 49.80 & 112 & 51.14 & 22 & 47.83 & 256 & 50.20 & \\
\hline & 3 & 61 & 24.90 & 51 & 23.29 & 4 & 8.70 & 116 & 22.75 & \\
\hline & $>3$ & 11 & 4.49 & 20 & 9.13 & 12 & 26.09 & 43 & 8.43 & \\
\hline & Total & 245 & 100 & 219 & 100 & 46 & 100 & 510 & 100 & \\
\hline
\end{tabular}

Table 11: Relationship of pregnancy characteristics with various degree of anaemia in the study subjects.

\begin{tabular}{|c|c|c|c|c|c|c|c|c|c|c|}
\hline & \multirow{3}{*}{ Variable } & \multicolumn{8}{|c|}{ Degree of anaemia } & \multirow{3}{*}{ Significance } \\
\hline & & \multicolumn{2}{|c|}{ Mild (n=245) } & \multicolumn{2}{|c|}{ Moderate $(n=219)$} & \multicolumn{2}{|c|}{ Severe $(n=46)$} & \multicolumn{2}{|c|}{ Total (510) } & \\
\hline & & $\begin{array}{l}\text { No. of } \\
\text { patients }\end{array}$ & $\%$ & $\begin{array}{l}\text { No. of } \\
\text { patients }\end{array}$ & $\%$ & $\begin{array}{l}\text { No. of } \\
\text { patients }\end{array}$ & $\%$ & $\begin{array}{l}\text { No. of } \\
\text { patients }\end{array}$ & $\%$ & \\
\hline \multirow{3}{*}{$\begin{array}{l}\text { Pregnancy } \\
\text { cha- } \\
\text { racteristics }\end{array}$} & Singleton & 219 & 89.39 & 209 & 95.43 & 46 & 100.00 & 474 & 92.94 & \multirow{3}{*}{$\begin{array}{l}\chi^{2}=10.28 \\
d f=2 \\
p=0.005\end{array}$} \\
\hline & Multiple & 26 & 10.61 & 10 & 4.57 & 0 & 0.00 & 36 & 7.06 & \\
\hline & Total & 245 & 100 & 219 & 100 & 46 & 100 & 510 & 100 & \\
\hline
\end{tabular}

Maximum number of cases i.e., 276 (54.1\%) from joint family (Table 6).

Majority of cases were from Hindu religion 455 (89.2\%) followed by Muslim i.e., 44 (8.6\%) (Table 7).

Most of the cases were from under nutrition group i.e., $45.88 \%$ followed by normal BMI i.e., $34.5 \%$, in all the 3 group (Table 8).
Maximum number of study population has weight gain between 5.1 to $9 \mathrm{~kg}$ during pregnancy i.e., 164 (32.16\%) followed by 3 to $5 \mathrm{~kg}$ i.e., $26.86 \%$ (Table 9 ).

Most of them were $2^{\text {nd }}$ para i.e., $256(50.2 \%)$ (Table 10).

Prevalence of anaemia was more among women having spacing between pregnancy $<2$ years i.e., 61.2\% (Table 11). 
Table 12: Relationship of dietary habit with various degree of anaemia in the study subjects.

\begin{tabular}{|c|c|c|c|c|c|c|c|c|c|c|}
\hline & \multirow{3}{*}{ Variable } & \multicolumn{8}{|c|}{ Degree of anaemia } & \multirow{3}{*}{ Significance } \\
\hline & & \multicolumn{2}{|c|}{ Mild (n=245) } & \multicolumn{2}{|c|}{ Moderate $(n=219$} & \multicolumn{2}{|c|}{ Severe $(n=46)$} & \multicolumn{2}{|c|}{ Total (510) } & \\
\hline & & $\begin{array}{l}\text { No. of } \\
\text { patients }\end{array}$ & $\%$ & $\begin{array}{l}\text { No. of } \\
\text { patients }\end{array}$ & $\%$ & $\begin{array}{l}\text { No. of } \\
\text { patients }\end{array}$ & $\%$ & $\begin{array}{l}\text { No. of } \\
\text { patients }\end{array}$ & $\%$ & \\
\hline \multirow{4}{*}{$\begin{array}{l}\text { Dietary } \\
\text { habit }\end{array}$} & Vegetarian & 178 & 72.65 & 122 & 55.71 & 26 & 56.52 & 326 & 63.92 & \multirow{4}{*}{$\begin{array}{l}\chi^{2}=21.32 \\
d f=4 \\
p<0.05\end{array}$} \\
\hline & Non-vegetarian & 51 & 20.82 & 62 & 28.31 & 17 & 36.96 & 130 & 25.49 & \\
\hline & Mixed & 16 & 6.53 & 35 & 15.98 & 3 & 6.52 & 54 & 10.59 & \\
\hline & Total & 245 & 100 & 219 & 100 & 46 & 100 & 510 & 100 & \\
\hline
\end{tabular}

Table 13: Relationship of iron folic acid prophylaxis in present pregnancy with various degree of anaemia in the study subjects.

\begin{tabular}{|c|c|c|c|c|c|c|c|c|c|c|}
\hline & \multirow{3}{*}{ Variable } & \multicolumn{8}{|c|}{ Degree of anaemia } & \multirow{3}{*}{ Significance } \\
\hline & & \multicolumn{2}{|c|}{ Mild (n=245) } & \multicolumn{2}{|c|}{ Moderate $(n=219)$} & \multicolumn{2}{|c|}{ Severe $(n=46)$} & \multicolumn{2}{|c|}{ Total (510) } & \\
\hline & & $\begin{array}{l}\text { No. of } \\
\text { patients }\end{array}$ & $\%$ & $\begin{array}{l}\text { No. of } \\
\text { patients }\end{array}$ & $\%$ & $\begin{array}{l}\text { No. of } \\
\text { patients }\end{array}$ & $\%$ & $\begin{array}{l}\text { No. of } \\
\text { patients }\end{array}$ & $\%$ & \\
\hline \multirow{4}{*}{$\begin{array}{l}\text { Iron folic } \\
\text { acid } \\
\text { prophylaxis } \\
\text { in present } \\
\text { pregnancy }\end{array}$} & Regular & 61 & 24.90 & 26 & 11.87 & 0 & 0.00 & 87 & 17.06 & \multirow{4}{*}{$\begin{array}{l}\chi^{2}=37.598 \\
d f=4 \\
p=1.356\end{array}$} \\
\hline & $\begin{array}{l}\text { Yes but } \\
\text { not regular }\end{array}$ & 100 & 40.82 & 116 & 52.97 & 15 & 32.61 & 231 & 45.29 & \\
\hline & No & 84 & 34.29 & 77 & 35.16 & 31 & 67.39 & 192 & 37.65 & \\
\hline & Total & 245 & 100 & 219 & 100 & 46 & 100 & 510 & 100 & \\
\hline
\end{tabular}

Table 14: Relationship of number of antenatal visits with various degree of anaemia in the study subjects.

\begin{tabular}{|c|c|c|c|c|c|c|c|c|c|c|}
\hline & \multirow{3}{*}{ Variable } & \multicolumn{8}{|c|}{ Degree of anaemia } & \multirow{3}{*}{ Significance } \\
\hline & & \multicolumn{2}{|c|}{ Mild (n=245) } & \multicolumn{2}{|c|}{ Moderate $(n=219)$} & \multicolumn{2}{|c|}{ Severe $(n=46)$} & \multicolumn{2}{|c|}{ Total (510) } & \\
\hline & & $\begin{array}{l}\text { No. of } \\
\text { patients }\end{array}$ & $\%$ & $\begin{array}{l}\text { No. of } \\
\text { patients }\end{array}$ & $\%$ & $\begin{array}{l}\text { No. of } \\
\text { patients }\end{array}$ & $\%$ & $\begin{array}{l}\text { No. of } \\
\text { patients }\end{array}$ & $\%$ & \\
\hline \multirow{4}{*}{ ANC visits } & $<4$ & 130 & 53.06 & 123 & 56.16 & 25 & 54.35 & 278 & 54.51 & \multirow{4}{*}{$\begin{array}{l}\chi^{2}=5.664 \\
d f=413 \\
p=0.226\end{array}$} \\
\hline & $4-8$ & 63 & 25.71 & 66 & 30.14 & 15 & 32.61 & 144 & 28.24 & \\
\hline & $>10$ & 52 & 21.22 & 30 & 13.70 & 6 & 13.04 & 88 & 17.25 & \\
\hline & Total & 245 & 100 & 219 & 100 & 46 & 100 & 510 & 100 & \\
\hline
\end{tabular}

Maximum number of study group women were vegetarian $326(63.92 \%)$ (Table 12).

Most of them were taking IFA prophylaxis irregularly i.e., 231 (45.29\%) (Table 13).

Maximum number of pregnant anaemic women had <4 antenatal visits i.e., $278(54.51 \%)$ followed by $4-8$ number of visits 144 (28.24\%) (Table 14).

\section{DISCUSSION}

Study done by Mangla et al at in rural area of Haryana found a unusually high prevalence anemia $(98 \%)$ in rural Haryana. ${ }^{7}$ And a study conducted by Agarwal et al found a very high prevalence of $91 \%$, and Baig Ansari et al. ${ }^{8}$ found high prevalence $90.5 \%$ similar to this study. ${ }^{9}$ Study by Mangla et al studied maximum number of anaemic pregnant women in the age group of 20-29 years i.e., $70.82 \%$ Prashant et al also had similar results. ${ }^{7,10}$
Study done by Dey et al shows prevalence of anaemia was more among primary educated women (58.5\%). ${ }^{11}$ Similarly, Ghazi et al studied degree of mild and moderately anaemic women among primarily educated women.

Study done by Rajamouli et al on pregnant women, attending the maternity clinic of rural health training centre and teaching hospital of Chalmeda Anand Rao Institute of Medical Sciences Karimnagar, Telangana, India shows high prevalence of anaemia among housewife and agricultural labours i.e., $152(96.8 \%) .{ }^{14}$ similar study done by Prashant et al prevalence was $63.5 \%$ among housewives. ${ }^{10}$

Study done by Gerald et al at Gulu and Hoima regional hospitals located in Northern and Western Uganda, taking 743 pregnant women, mostly studied population were from lowest wealth index i.e., $462(21.7 \%) .{ }^{15}$ 
It was observed by Ghazi et al in their study that most of the anaemic women were from low socio-economic status $136(22.66 \%) .^{13}$

Prashant et al performed their study among 400 pregnant women residing in $\mathrm{PHC}$ Handignur found more prevalence of anaemia in Hindu family i.e., $86.5 \% .^{10}$ Similarly study done by Madhavi et al where Hindus were $88.8 \%$, while Priyanka et al found Hindus were $62 \% .{ }^{19,20}$

Ravishankaran et al found more prevalence among those women living in joint family i.e., 56\%. ${ }^{16}$ Bisoi et al and Gautam et al studied similar result among joint family women. ${ }^{17,18}$

Study done by Dey et al shows prevalence of anaemia was $65.6 \%$ among undernutrition group. ${ }^{11}$ Lin et al study shows mostly women had low BMI i.e., $21.40 \%$ similarly Awoke et al studied, $22.89 \%$ were under nutritioned..$^{21,22}$

A study done by Taner et al shows $52.20 \%$ of pregnant women gains weight $<10 \mathrm{~kg}$. ${ }^{12}$

Anaemia was found more among pregnant women having high parity in the study done by Shwetha et al and Anlaakuu et al. ${ }^{4,23}$

Bisoi et al found more prevalence of anaemia i.e., $88.9 \%$ among pregnant women having $<2$ year spacing since last delivery. ${ }^{17}$ Huma et al in their study reported similar result. $^{24}$

Study done by Rajamouli et al attending the maternity clinic of rural health training centre and teaching hospital of Chalmeda Anand Rao institute of medical sciences Karimnagar, Telangana, India in 2015, they found high prevalence of anaemia among vegetarian i.e., 108 $(40.14 \%) .^{14}$

Study by Mangla et al at found maximum number of anaemic pregnant women was taking IFA irregularly i.e. $42.03 \%$. $^{7}$

Even if the woman had a normal amount of iron before pregnancy, more is needed during pregnancy. This is due to the growth of the foetus, the uterus, the placenta, increased RBC mass and many other changes taking place in a pregnant mother that require many nutrients, especially iron and folic acid. This requirement is not met by food alone in developing countries, and therefore oral iron supplementation is justified. Therefore, to reduce the risk of maternal anaemia, iron deficiency and poor pregnancy outcomes, the WHO guidelines recommend a standard daily oral dose of $60 \mathrm{mg}$ iron and $400 \mu \mathrm{g}$ folic acid supplements throughout pregnancy, to begin as early as possible as a part of antenatal care (ANC) programs.

WHO recommends that a minimum 4 ANC visits and ideally 13 ANC visits should be done by pregnant women during pregnancy. Proper antenatal checkup leads to early diagnosis and management of anemia and other related infection and factors which can aggravate the condition on time.

Taner et al found anaemia more common among women having ANC visits $5-10$ is $45.66 \% .^{12}$

\section{CONCLUSION}

Anemia is the commonest medical disorder in pregnancy which exists world-wide and is a very common problem in most of the developing countries. It is not only a medical problem, but is a major public health problem. In country like India, it is frequently severe and contributes significantly to maternal mortality and reproductive health morbidity. It causes direct as well indirect deaths in form of cardiac failure, hemorrhage, infection and preeclampsia. Anemia is also responsible for adverse fetal outcome in the form of spontaneous abortions, preterm deliveries, low birth weight babies and intra uterine growth restriction.

Considering the high prevalence of anaemia in Vindhya region, extensive efforts should be made not only to correct anaemia but to prevent anaemia. Iron supplementation during pregnancy in mothers improves iron status during pregnancy and postpartum period, thus providing some protection against iron deficiency in the subsequent pregnancy. Ensuring maternal iron sufficiency during gestation is the most cost-effective method of preventing perinatal iron deficiency and related morbidities.

Various programme for anaemia control should be executed more resourcefully to overcome it. Awareness is to be increased about dietary habits, small family norms, birth intervals and regular antenatal visits. Proper antenatal care is the basic requirement for prevention, early detection and treatment of anemia.

Strong reinforcement of government scheme should be done at Anganwadi, $\mathrm{CHC}$, PHC to ensure prevention as well as early detection of anaemia. One should make sure that the services should reach the beneficiaries especially in peripheral areas where prevalence of these problems are maximum.

\section{Funding: No funding sources}

Conflict of interest: None declared

Ethical approval: The study was approved by the Institutional Ethics Committee

\section{REFERENCES}

1. Hoffman BL. Williams obstetrics, $25^{\text {th }}$ edition. Data from centres for disease control and prevention; 1989:1075.

2. Purandare CA, Dalal RA, Purandare CB. Anaemia in pregnancy. J Evolut Med Dent Sci. 2013;35(2):1-59. 
3. De Mayer EM, Tegman A. Prevalence of anaemia in the World. World Health Organisation Qlty. 1998;38:302-16.

4. Shwetha, Prasad KN. Prevalence of anemia among pregnant women. A cross sectional study. Int J Med Sci Public Health. 2018;7(12):1023-6.

5. Park K, Parks textbook of preventive and social medicine. $24^{\text {th }}$ edition, epidemiology of nutritional and food related disease and its prevention and control; 679680.

6. NFHS-4. National Family Health Survey. International institute for population science (IIPS) and ICF. 2017. NFHS-4, 2015-16.

7. Mangla M, Singla D. Prevalence of anaemia among pregnant women in rural India: a longitudinal observational study. Int $\mathrm{J}$ Reprod Contracept Obstet Gynecol. 2016;5(10):3500-5.

8. Agarwal KN, Agarwal DK. Prevalence of anaemia in pregnant and lactating women in India. Indian $\mathbf{J}$ Med. 2006;124(8):173-84.

9. Baig-Ansari N, Badruddin SH, Karmaliani R, Harris H, Jehan I, Pasha O, et al. Anemia prevalence and risk factor in pregnant women in an urban area of Pakistan. Food Nutr Bull. 2008;29:132-9.

10. Prashant D. Prevalence of anaemia among pregnant women attending antenatal clinics in rural field practice area of Jawaharlal Nehru Medical college, Belagavi, Karnataka, India. Int J Community Med Public Health. 2017;4(2):537-41.

11. Dey S, Goswami S, Goswami M. Prevalence of anaemia in women of reproductive age in Meghalaya: a logistic regression analysis. Turk $\mathrm{J}$ Med Sci. 2010;40(5):783-9.

12. Taner CE, Ekin A, Solmaz U, Gezer C, Çetin B, Keleşoğlu M, Erpala MB, et al. Prevalence and risk factors of anemia among pregnant women attending a high-volume tertiary care center for delivery. J Turk Ger Gynecol Assoc. 2015;16(4):231-6.

13. Ghazi R, Wahid A, Ahmed HM. Prevalence and severity of anemia among pregnant women in primary health centers/Erbil City. Kurdistan J Appl Res. 2017;2(2):52-7.

14. Rajamouli J, Ravinder A, SCK Reddy, Pambi S. Study on prevalence of anemia among pregnant women attending antenatal clinic at rural health training centre (RHTC) and chalmeda anand rao institute of medical sciences teaching hospital, Karimnagar, Telangana, India. Int J Contemp Med Res. 2016;3(8):2388-91.
15. Obai G, Odongo P, Wanyama R. Prevalence of anaemia and associated risk factors among pregnant women attending antenatal care in Gulu and Hoima Regional Hospitals in Uganda: a cross sectional study. BMC Pregnancy Childbirth. 2016;16(1):76.

16. Suryanarayana R, Chandrappa M, Santhuram AN, Prathima S, Sheela SR. Prospective study on prevalence of anemia of pregnant women and its outcome: a community based study. J Family Med Prim Care. 2017;6:739-43

17. Bisoi S, Haldar D, Majumdar TK, Bhattacharya N, Sarkar GN, Ray SK. Correlates of anemia among pregnant women in a rural area of West Bengal. The Journal of Family Welfare. 2011;57(1):72-8

18. Gautam V, Bansal Y, Taneja DK, Shah R. Prevalence of anaemia amongst pregnant women and its sociodemographic associates in rural area of Delhi. Ind $\mathrm{J}$ Comm Med. 2002;XXVII(4):157-60.

19. Madhavi LH, Singh HKG. Nutritional status of rural pregnant women. Peoples J Sci Res. 2011;4(2):20-3.

20. Priyanka SP, Mehta S, Nagar R. Prevalence of anemia and socio-demographic factors associated with anemia among pregnant women attending antenatal Hospital in Jaipur City, India. IOSR-JPBS. 2013;6(3):1-5.

21. Lin L, Wei Y, Zhu W, Wang C, Su R, Feng H, et al. Prevalence, risk factors and associated adverse pregnancy outcomes of anaemia in Chinese pregnant women: a multicentre retrospective study. BMC Pregnancy Childbirth. 2018;18(1):111.

22. Kebede A, Gerensea H, Amare F, Tesfay Y, Teklay G. The magnitude of anemia and associated factors among pregnant women attending public institutions of Shire Town, Shire, Tigray, Northern Ethiopia, 2018. BMC Res Notes. 2018;11(1):1-6.

23. Anlaakuu P, Anto F. Anaemia in pregnancy and associated factors: a cross sectional study of antenatal attendants at the Sunyani Municipal Hospital, Ghana. BMC Res Notes. 2017;10(1):402.

24. Naz H, Begum B. Prevalence and associated risk factors and of anaemia in pregnant women in a teaching hospital, Korangi Industrial Area. Pak J Surg. 2013;29(2):131-3.

Cite this article as: Yadav S, Yadav K, Shukla P. Burden of anemia and its associated factors among pregnant women of Vindhya region: prospective observational study. Int J Reprod Contracept Obstet Gynecol 2020;9:3697-703. 